American Journal of Pharmaceutical Education 2017; 81 (6) Article 114.

\title{
RESEARCH
}

\section{A Qualitative Study of Motivating Factors for Pharmacy Student Leadership}

\author{
R. Joel Moore, PharmD, Diane B. Ginsburg, PhD, MS \\ The University of Texas at Austin College of Pharmacy, Austin, Texas \\ Submitted June 29, 2016; accepted November 30, 2016; published August 2017.
}

Objective. To understand what motivates student pharmacists to seek a leadership position while in the professional pharmacy program and why these students choose to lead in a particular organization.

Methods. A qualitative study was used to answer the research questions. Current student leaders were recruited to participate, and each completed a pre-interview questionnaire and a one-hour interview. All interviews were transcribed, and an interpretive phenomenological approach was used to describe, code, and analyze the experiences.

Results. Student leaders were motivated to serve in a leadership position for four reasons: networking opportunities, belief in an organization's mission, ability to affect change, and legacy. Additionally, prior leadership experience and influence played major roles in these student leaders' pursuit of a position.

Conclusion. Networking, belief in an organization's mission, ability to affect change, and legacy are the four primary motivating factors for student leadership while in the professional pharmacy program. Knowing these factors should help direct resources in organizational and college efforts to produce qualified and impactful pharmacist leaders.

Keywords: leadership, motivation, student

\section{INTRODUCTION}

Leadership development is a tenet of the professional development of student pharmacists. The Center for Advancement of Pharmacy Education (CAPE) Educational Outcomes includes leadership as part of Domain 4: Personal and Professional Development, in its 2013 publication. ${ }^{1}$ Pharmacy schools have developed and sponsored curricular and co-curricular activities with the intent of developing student leaders. The University of Texas at Austin College of Pharmacy (UTCOP) has 16 organizations for students in the professional pharmacy program, with the majority of these organizations receiving college funds to achieve their respective missions. ${ }^{2}$ The efforts of developing leadership in student pharmacists, on the part of the college of pharmacy (COP) and its student organizations, should be further examined, particularly since considerable resources are expended on these efforts.

Researchers have studied individual characteristics that predict how likely a student pharmacist is to assume a leadership role while in a professional pharmacy program. For example, Kiersma and colleagues found that as a student's pre-pharmacy grade point average (GPA)

Corresponding Author: R. Joel Moore, Pharmacotherapy Education \& Research Center, 7703 Floyd Curl Drive, MC 6220, San Antonio, TX 78229-3900. Tel: 210-567-8355.

E-mail: robertjoelmoore@gmail.com increased, that student was less likely to hold a leadership position. Also, student pharmacists in the third and fourth professional years (P3 and $\mathrm{P} 4)$ were more likely to be involved in student organizations than students in the first and second professional years (P1 and P2). Recently, Phillips and colleagues found that $\mathrm{P} 4 \mathrm{~s}$ who held leadership positions while in the professional pharmacy program were motivated to lead because of three factors: interest in developing leadership skills, enjoyment of the feeling of giving back, and the ability to include it as an accomplishment on a curriculum vitae (CV). Additionally, this study assessed motivating factors for student leaders in a variety of positions, ranging from committee chairs to non-presidential officers to presidential officers. ${ }^{4}$

However, there have been no studies to identify why student pharmacists choose to lead in a particular organization. Specifically, it is unknown if the factors that motivate a student pharmacist to serve in student government are the same as those for a student pharmacist who leads in a nationally affiliated organization. Additionally, one study on motivating factors at one school may not be sufficient to generalize to all student pharmacists.

The purpose of this research study was to identify why student pharmacists choose to serve as a leader, and how these student leaders choose a particular organization to lead. The questions this research sought to answer 


\section{American Journal of Pharmaceutical Education 2017; 81 (6) Article 114.}

were twofold: Why does a student pharmacist seek to serve in a leadership capacity, and what characteristics about different student organizations direct these student leaders to choose one versus another (student government vs. a nationally affiliated organization)?

Additional attention was given to those characteristics the student leaders believed were essential in executing their duties. Because this study took an inductive approach, a specific hypothesis was not tested; rather, commonalities were identified across student leaders, previous and current, based on the research questions above.

A choice model for why students in the professional pharmacy program choose to serve in a leadership position and why these students choose to lead in a particular organization could be helpful for organization leaders in recruiting future leaders. Furthermore, the results from this research will inform future inquiries and further expand our knowledge of why student pharmacists seek leadership activities while in the professional program.

\section{METHODS}

A qualitative research approach was appropriate for this study given the research questions and the goal to develop an in-depth understanding of the student experiences in seeking and holding a leadership position while in pharmacy school. This method allowed the researchers to hear the voices of participants communicating their experiences with this phenomenon. The specific phenomenon under investigation in this study was the choice to serve as a student leader. The advantage to qualitative exploration is the ability to highlight complex phenomena by empowering individuals to tell their stories. ${ }^{5}$ Therefore, this study utilized a qualitative method with a phenomenological approach. This approach allowed for the determination of what an experience meant to an individual and, subsequently, the participant's ability to describe the experience. ${ }^{5}$ From individual descriptions, common themes were derived. ${ }^{6,7}$ Data collection involved interviewing individuals who experienced the phenomenon being studied. ${ }^{5}$ Participants in this study were able to describe their experience with choosing to hold a leadership position and identified factors that contributed to their decision-making.

In addition to in-depth interviews, Creswell advocates the gathering of additional data to help depict a more holistic view of a participant's experience. ${ }^{6}$ Five sources of data are included in this study. The data sources include the pre-interview questionnaire, interview transcripts, field notes, and archival information about the organizations (eg, Web information). The researcher also kept a reflective journal to record insights gleaned from the participants.
One round of in-depth, semi-structured interviews of participants was used in this study. Semi-structured interviews rely on a predetermined set of questions, but follow-up questions may be asked at the discretion of the interviewer to further clarify a participant's statement or expound upon an idea mentioned by a participant. This interview method is adapted from Seidman's model, which involves three 90-minute interviews. Seidman proposed this method in order to develop a relationship with study participants, enabling them to share their experiences more readily. ${ }^{5}$ However, because the researcher in this study already had a working relationship with study participants, the number of interviews was reduced to one. This revised methodology allowed for more participants to be interviewed, with the goal of creating a broader understanding of what motivates student leaders to serve.

All organization presidents within the UTCOP were recruited to the study in addition to four past pharmacy council (student government) presidents and 2014-2015 pharmacy council executive committee members. Participant selection was based on individual response and availability to complete the study. Twenty-five student leaders were recruited to participate in the study. In total, 22 student leaders participated and were interviewed. Participants were each given a pseudonym to de-identify their information. All interviews were transcribed, and an interpretive phenomenological approach was used to describe, code, and analyze the experiences. Dedoose, a Web application for qualitative and mixed methods research, was used to code and analyze the transcripts. ${ }^{8}$ Emergent themes from all data sources informed the findings about the leadership choice process for student pharmacists and the relevant factors influencing the choice of an organization to lead.

The interview protocol contains a standardized set of questions to understand a participant's experience with choosing a leadership position. Open-ended questions were used to encourage participation and description of the phenomenon. A pre-interview questionnaire was administered to the participants prior to the interview to gather demographic and other information to be used during the interview.

The research protocol was submitted to the University of Texas at Austin's Institutional Review Board and was granted exempt status.

\section{RESULTS}

The individual participant characteristics are detailed in Table 1. Notably, there were 22 participants: 13 females and 9 males. The average age at the time of holding office (adjustment made for those participants who were former pharmacy council presidents) was 
American Journal of Pharmaceutical Education 2017; 81 (6) Article 114.

Table 1. Participant Characteristics and Demographic Information

\begin{tabular}{|c|c|c|c|c|c|c|c|c|c|}
\hline $\begin{array}{l}\text { Participant } \\
\text { Pseudonym }\end{array}$ & Gender & $\begin{array}{l}\text { Age (at the } \\
\text { time of } \\
\text { office) }\end{array}$ & $\begin{array}{c}\text { Race/ } \\
\text { Ethnicity }\end{array}$ & $\begin{array}{c}\text { Marital } \\
\text { Status }\end{array}$ & $\begin{array}{l}\text { Children/ } \\
\text { Dependents }\end{array}$ & $\begin{array}{c}\text { Prior } \\
\text { Degree(s) }\end{array}$ & $\begin{array}{c}\text { Pre-Pharmacy } \\
\text { GPA }\end{array}$ & $\begin{array}{l}\text { PCAT } \\
\text { Score }\end{array}$ & $\begin{array}{c}\text { Prior } \\
\text { Leadership } \\
\text { Positions }\end{array}$ \\
\hline Elizabeth & $\mathrm{F}$ & 29 & Asian & Single & No & BS & 3.30 & 94 & 14 \\
\hline Ashley & $\mathrm{F}$ & 24 & Caucasian & Single & No & BS & 3.40 & 89 & 5 \\
\hline Richard & M & 24 & Asian & Single & No & No & 3.40 & 98 & 6 \\
\hline Shannon & $\mathrm{F}$ & 21 & Caucasian & Single & No & No & 3.98 & 96 & 6 \\
\hline Adam & M & 23 & $\begin{array}{l}\text { Caucasian/ } \\
\text { Hispanic or } \\
\text { Latino }\end{array}$ & Single & No & No & 3.18 & 64 & 10 \\
\hline John & M & 26 & Asian & Single & No & BS & 3.75 & 73 & 4 \\
\hline Danny & M & 24 & N/A & Single & No & No & 3.41 & N/A & 8 \\
\hline Cathy & $\mathrm{F}$ & 22 & $\begin{array}{l}\text { Caucasian/ } \\
\text { Hispanic or } \\
\text { Latino }\end{array}$ & Single & No & No & 4.00 & 77 & 2 \\
\hline Donald & $\mathrm{M}$ & 30 & Caucasian & Married & No & BS & 4.00 & 92 & 5 \\
\hline Lacey & $\mathrm{F}$ & 23 & Asian & Single & No & BA & 3.10 & N/A & 14 \\
\hline Carl & M & 23 & Asian & Single & No & No & 3.80 & 99 & 11 \\
\hline Judy & $\mathrm{F}$ & 34 & $\begin{array}{l}\text { Hispanic or } \\
\text { Latino }\end{array}$ & Married & No & BBA & 4.00 & 68 & 6 \\
\hline Diane & $\mathrm{F}$ & 23 & Asian & Single & No & No & 3.60 & 84 & 4 \\
\hline William & M & 23 & Asian & Single & No & No & 3.70 & 85 & 4 \\
\hline Laura & $\mathrm{F}$ & 24 & Caucasian & Single & No & BS & 3.44 & 89 & 4 \\
\hline Jennifer & $\mathrm{F}$ & 23 & $\begin{array}{l}\text { Hispanic or } \\
\text { Latino }\end{array}$ & Single & No & No & 3.66 & 64 & 5 \\
\hline Hugh & M & 24 & Caucasian & Single & No & No & 3.70 & 78 & 4 \\
\hline Susan & $\mathrm{F}$ & 23 & Caucasian & Single & No & No & 4.00 & 90 & 2 \\
\hline Patrick & $\mathrm{M}$ & N/A & Asian & Single & No & No & N/A & N/A & 13 \\
\hline Donna & $\mathrm{F}$ & 23 & Asian & Single & No & BS & 3.70 & 98 & 3 \\
\hline Leigh & $\mathrm{F}$ & 29 & Caucasian & Single & No & BA & 4.00 & 92 & 11 \\
\hline Janet & $\mathrm{F}$ & 22 & Caucasian & Single & No & No & 3.76 & 98 & 12 \\
\hline
\end{tabular}

24.6 years. The most common race/ethnicity was Caucasian (10/22 participants or $45 \%)$. Two participants were married (9\%) and no participants had children or dependents. Nine participants $(41 \%)$ had a prior degree before entering the professional pharmacy program. Their average pre-pharmacy GPA was 3.66, with an average PCAT score of 86. Finally, participants held an average of seven leadership positions prior to assuming the position of interest in this study.

From the interviews, three dominant themes arose: motivating factors, experience, and influence. Furthermore, the four subthemes that arose within the first theme of motivating factors were networking, belief in the organization's mission, ability to affect change, and legacy.

The first dominant theme that arose from the interviews was motivating factors. The four most frequently mentioned motivating factors were networking, belief in the organization's mission, ability to affect change, and legacy. Between the two comparison groups (student government and nationally affiliated organizations), all four of these motivating factors were maintained categorically.

Networking was a motivating factor for all student leaders regardless of the type of organization they were leading. While the types of networking opportunities differed between the two groups, student leaders in both groups were motivated to serve as a leader to establish a professional network. Janet, a student government leader, said, "Another thing is, specifically in the college of pharmacy, the ability to really get to know faculty. I had never really known faculty as an undergrad. I never really talked to them. I was in big classes; I didn't have an interest. But it seems like from what I've seen from upperclassmen, the people who are more involved, knew the faculty better. That's something specifically at the college of pharmacy that kind of attracted me to leadership."

Additionally, Elizabeth, a leader in a nationally affiliated organization, said, "For me it was opportunity. The ... presidency opens a lot of doors, and it gives me a lot of exposure to different networking opportunities, 


\section{American Journal of Pharmaceutical Education 2017; 81 (6) Article 114.}

different avenues that I normally would not have access to." From these two quotes, and the many other experiences shared during interviews, student leaders choose to serve in leadership capacities to begin forming their professional network. Student leaders in student government were motivated to lead because they wanted to form a more local network compared to those leaders in nationally affiliated organizations. These local networking opportunities included members of college faculty and administration and university administration. Student leaders in nationally affiliated organizations looked for networking opportunities more broadly in the field of pharmacy (ie, on the state and/or national level).

The next three motivating factors for student leadership are best understood in a continuum: belief in the organization's mission, ability to affect change, and legacy. Furthermore, these motivating factors were found between both groups being compared. Shannon, a student leader in a nationally affiliated organization, said, "I really had a passion for the goal of organization. I saw a lot of opportunities for what it could do. Some ideas that I had with what we could do and I was really excited about that." Additionally, Leigh, a student government leader, said, "I saw the value that [the student government] had overall: the curriculum and the assessment piece we have. In terms of things that I saw that I felt needed to be changed or improved upon and the ability to get in there and work towards that and recruit people who are excited about doing those types of things." This initial belief in the organization's mission motivated these students to become further involved in these organizations.

Once these students gained their initial exposure to and belief in their preferred organization, they began to observe areas within the organization they thought could be improved. These experiences were coded as "ability to affect change." Commonly, student leaders described their overall experience in the organization as positive; however, many identified areas within the organization that needed revision or improvement. Lacey, a student leader in a nationally affiliated organization, said, "I feel like I'm able to try to implement some of my goals as president versus just being a normal member where I don't really have as much of a voice." Furthermore, Leigh said, "You're in a position of power to where you could influence people the right way to the way you see your organization heading." The combination of belief in organization's mission and ability to affect change motivated these students to seriously consider a leadership position within the organization.

The final motivating factor in the continuum is legacy; that is, students were motivated to pursue a leadership position within their preferred organization because they wanted their improvements to the organization to be worthwhile and sustainable. William, a student leader in a nationally affiliated organization, said, "Also going on with this, leaving an impact on the college and leaving a legacy. One of the things that I did just a couple weeks ago was the president-elect position and that's something we'd never done before. I was talking to [the organization's faculty advisers] about it and they were really happy about the idea of doing it and that we did do it. And they were like, 'this is your legacy, it's what you started.' So I think that's really cool."

Patrick, a student government leader, said, "I think the biggest thing is the legacy. I think that's been my favorite part of looking back at what you did. Where you do something that made a change to where people will still remember you or you make a change or did you leave the organization better than when you got it." Legacy may be viewed as the natural outcome of the first two motivating factors. In other words, student leaders want to not only improve the organization for the year they are leading it, they also want the organization to continue to improve in part because of their leadership efforts. In this respect, legacy not only functioned as a motivating factor but also as a source of fulfillment from leading the organization.

The second dominant theme that arose from the interviews was leadership experience. Pre-pharmacy experience and pharmacy school experience (PSE) in leadership roles were highly associated with leadership roles while in the professional pharmacy program. The student leaders who participated in this study had, on average, held seven leadership positions before holding the position of interest (ie, the position under discussion in this study). This average includes both undergraduate and high school leadership experiences.

The third and final theme relating to student leaders' choice process was influence. Student leaders were influenced by their family, peers, and past officers to pursue a leadership position. While family and peer influences were more supportive than directive, past officers influenced student leaders to pursue a particular position; therefore, the latter influence is more directive. Furthermore, these three types of influence were consistent between the two groups of leaders compared. Janet described her grandmother's influence, saying, "And my grandmother has always been involved in twenty organizations at one time. Her whole life she's been involved in everything so that was something she always like really emphasized to me: how important it was to be involved in organizations that do things you are passionate about." In reviewing the student leaders' experiences with family influence, it is apparent that family members were 


\section{American Journal of Pharmaceutical Education 2017; 81 (6) Article 114.}

supportive and encouraging; however, family members did not typically play a role in directing a student leader to choose one organization over another.

Peer influence also played a prominent role in student leaders' choice process regardless of the type of organization in which they were seeking to lead. Diane described peer influence, saying, "My peers, of course, like friends I've made throughout school have always been encouraging. Actually, seeing my friends become leaders themselves has been very motivating, especially when you think your group of friends are slackers and then they're the ones that come up and surprise you and become a leader motivated myself to see what I could do." Specifically, Diane discussed the role that reinforcement from peers plays in leadership, saying, "My friends have always been encouraging after the event. After I took part in an event they would tell me it was very successful. They were very pleased by everything. I would say more in that regard they're more supportive after the fact, if that makes sense." As with family influence, peer influence functioned more as encouragement and affirmation than direction to a specific position.

The third and final type of influence that played a role in student leaders' choice process was the influence of past officers. While the student leader was a P1 or P2, they described being approached by the student holding the office of interest at the time and were encouraged to think about pursuing their position (eg, the presidency). Laura described a past officer's influence, saying, "She [the past president] talked to me about the idea of me running and that she thought that it would be a really good idea. I decided at that point that I was going to go ahead and run in the upcoming month for that." From this quote alone, and from the other experiences shared, it can be seen that the individuals who previously held the office of interest heavily influenced the student leaders in this study to pursue a particular position. While this influence certainly involved some degree of encouragement and affirmation, it was also directive. In other words, past officers would recommend consideration of a specific position (eg, the presidency over vice presidency). Past officer influence also was seen between both groups of leaders compared in this study.

One additional facet of leadership that was examined in this study, although not a main objective of the study, was the characteristics viewed by student leaders as important for holding their position. The four most frequently mentioned characteristics were communication, time management, delegation, and enthusiasm/passion. These characteristics fell into two different viewpoints. Some student leaders viewed these characteristics as essential before beginning his/her leadership experience (ie, as prerequisites), while the others viewed the leadership experience as an opportunity to develop and hone that particular characteristic or skill (ie, the leadership experience functioned as training).

Communication was the most frequently cited characteristic for being a successful leader. Discussing the significance of communication, Susan said, "I think it's really important to be able to communicate with other people. That's something that I've learned. I wasn't very good at communicating via e-mail and that's one of the most important things that I do." Laura described the importance of communication, saying, "I think one of the most important personal skills is being able to talk to people. This is not only talking about positive things, but about negative things as well, because as a leader you're always going to get the problem." In analyzing the transcripts, it became apparent that one type of communication was not emphasized over another. Student leaders regarded all forms of communication (eg, public speaking at meetings, e-mail correspondence with officers and/or members, or in-person discussions with college administration) as equally important in executing their duties.

The second most discussed leadership characteristic was time management. Janet gave her perspective on time management, saying, "The most important skill I think would probably be time management just because there are so many things going on. I think that is absolutely crucial to being successful in that role and not just getting completely overwhelmed." Judy's perspective of time management was slightly different. She said, "It's just a matter of you learning to balance school and life. We are going to do that one day when we graduate. If we don't learn by doing it now, I think that it will affect us in the future." In other words, while Janet viewed time management as a prerequisite for holding a position, Judy viewed this skill as one meant to be developed while in the professional pharmacy program for future use when practicing as a pharmacist.

The third most frequently mentioned leadership characteristic was delegation (ie, assigning the planning or execution of a task to a subordinate officer or member within the organization). Carl shared his perspective on delegation, saying, "The other thing that I think limits a lot of leaders, from my experience, is being able to delegate. I think there are a lot of leaders that are really good at communicating and at seeing a vision, but when it comes to delegating, that's what gets a lot of leaders. If you can't effectively delegate and keep everyone happy and motivated, that's kind of when your organization is at a standstill because you really can't do everything on your own. No organization can run with just like one visionary or 


\section{American Journal of Pharmaceutical Education 2017; 81 (6) Article 114.}

one genius. They can't do that. It needs to be ran by just ordinary people that are following. That's the other thing I think, being able to delegate and motivate, keep the energy level high."

As with the previously two mentioned characteristics, delegation was viewed as both a prerequisite and an area for growth while holding office. This characteristic was maintained across both groups of leaders interviewed in this study; however, it was more commonly mentioned among presidential officers than the executive committee members of the student government organization.

The fourth and final characteristic was enthusiasm/ passion. Unlike the previous three characteristics, this characteristic was viewed primarily as a prerequisite and coincides with the second motivating factor (ability to affect change). Hugh said, "Finally, passion. If you care about what you're doing, it's a lot easier to be a good leader." Furthermore, Ashley said, "I think if you're in a leadership position, especially as president, if you can exude those attitudes or be enthusiastic about what your organization is doing, then you're more than likely to have the support of your organization."

While in the professional pharmacy program, students choose to serve in a leadership capacity for four reasons: networking, belief in organization's mission, ability to affect change, and legacy. All four motivating factors were common to student leaders in nationally affiliated organizations and those in student government. Additionally, students were heavily influenced by others (family, peers, and past officers) to pursue a leadership position and their prior leadership experience played a role in their desire for future positions.

\section{DISCUSSION}

Based on the participants' shared experiences regarding the phenomenon of holding a leadership position while in the professional pharmacy program, a model for the student leadership choice process is proposed in Figure 1, with an explanation following.

Importantly, this process is fluid. In other words, student pharmacists do not leave one step and move on to the next step; they are continually moving between parts of this model in their choice process. Influence (from family, peers, and past officers) and prior leadership experience are the main initial reasons for a student pharmacist to consider serving in a leadership position. Then students continue gathering information about various organizations and the available positions within those organizations. Once a student pharmacist has decided to pursue a position, he or she weighs the benefits of serving in various leadership positions based on the four motivating factors as those factors apply to the individual student pharmacist's leadership goals. The student pharmacist then has a set of leadership positions that he or she considers pursuing. They engage in discussions with past officers who exert their influence on the potential leader and try to direct their decision-making to a particular position. Significantly, a student leader may repeat this process several times throughout the professional pharmacy program (as noted by the dotted lines in Figure 1) with each leadership position held counting as prior leadership experience.

Knowing what motivates student pharmacists to pursue a leadership position while in the professional pharmacy program will be helpful for student organizations. Specifically, these organizations will know what to focus on when advertising or recruiting potential leaders. An organization may, for example, enumerate the types of networking opportunities available to its leaders. These networking opportunities could be communicated to the organization's membership with an explanation of the potential benefits of having such a network. Additionally, an organization might market its leadership positions based on the ability of its leaders to make positive improvements within the organization and show how those improvements are sustainable. These opportunities might appeal to those potential leaders who want to affect change within the organization and, in so doing, leave a legacy.

Another implication of this research deals with the common thread of prior leadership experience among student leaders. Student pharmacists, upon matriculation to the professional program, should be strongly encouraged to take on less time-intensive leadership positions (eg, a committee co-chair or subcommittee chair) so they can start on their path to a more time-intensive position (eg, the presidency) if that is their goal. When P1s start the program, they are presented with the organizations' goals and missions in addition to available positions within the various organizations. More than 90 positions are reserved for incoming P1s every fall, and some students may be hesitant to apply for one of these co-curricular positions because of the intensive pharmacy curriculum. However, if a student pharmacist's goal is to eventually hold an executive-level officer position within a student organization, this study's results suggest that an early attainment of a leadership position (albeit less timeintensive) is warranted and recommended.

The final implication of this study pertains to the effect past officers can have on the future of their organization in grooming or coaching future leaders. Because past officers have a positive influence on student pharmacists pursuing leadership positions in this study, current officers should acknowledge the influence they can have 
American Journal of Pharmaceutical Education 2017; 81 (6) Article 114.

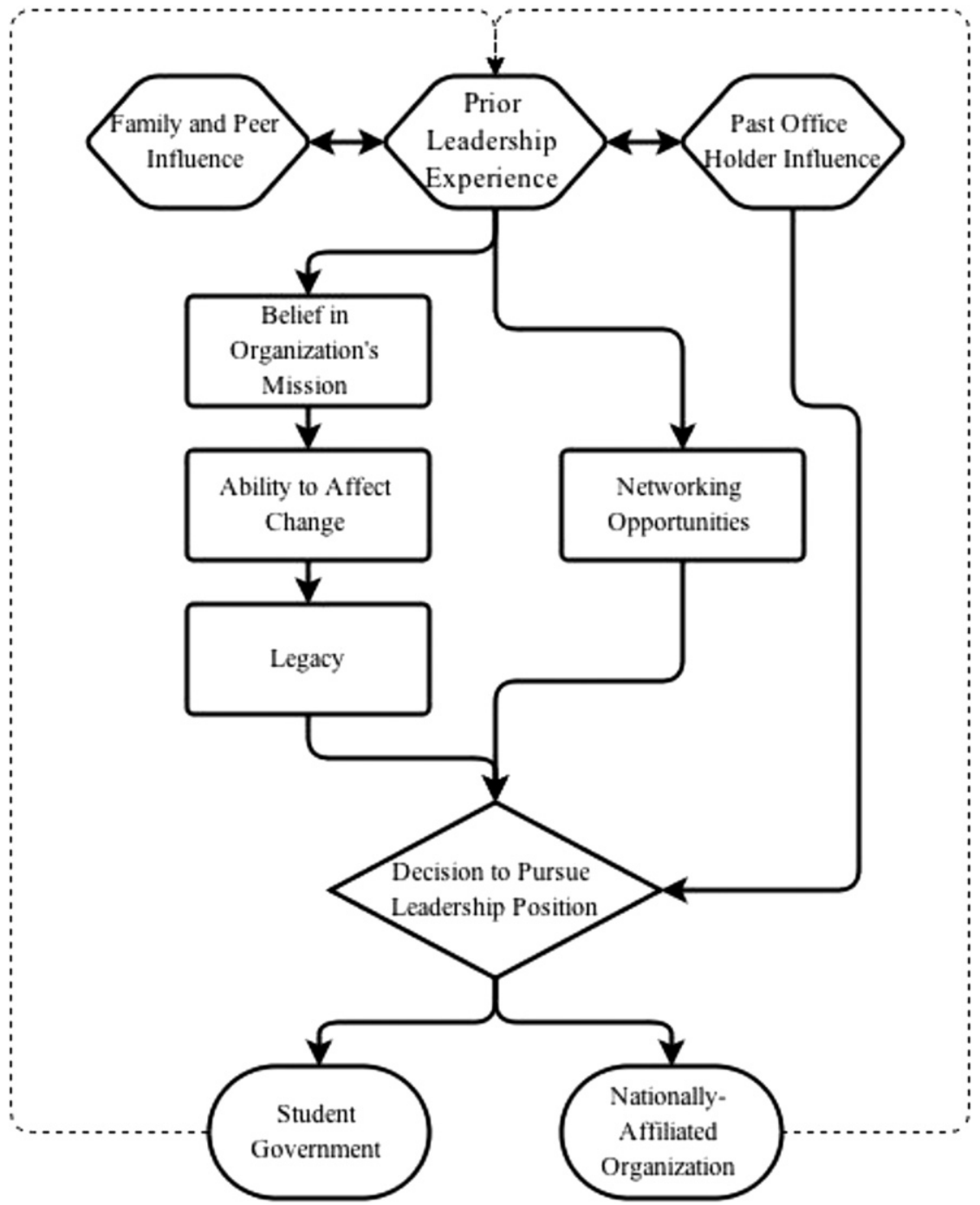

Figure 1. Proposed Model for Student Pharmacist Leadership Choice Process.

on members of their organization who are considering running for a leadership position in the future. If the individual who was encouraged to run ends up holding that office, it could be said that the past officer had a lasting impact on the organization (ie, legacy).

Finally, although not a major focus of this study, organizations would do well to develop those characteristics within their members that are regarded as important for being a successful leader. Particularly, organizations should develop or promote communication skills, time management, delegation, and passion/enthusiasm in their memberships. This would result in a pipeline, figuratively speaking, of individuals who are trained and capable of performing well as a leader within the organization.

Opportunities for future research in this area are numerous, especially because it has been minimally described in the literature. Primarily, a quantitative instrument should be developed to validate and expand these findings. Furthermore, because this study took an inductive approach, a deductive approach using a quantitative instrument would increase the generalizability of these findings and further our understanding of what motivates student pharmacists to lead. Additionally, a quantitative instrument could be distributed to more student leaders, including those in less time-intensive roles (eg, committee chairs). Comparisons could then be made to see if those who seek different kinds of leadership positions are motivated to serve for the same reasons. Additional opportunities for future research include evaluating the effectiveness of implementing marketing and grooming strategies within student organizations. For example, an organization could assess leadership before and after implementation of targeted marketed strategies and programs meant to develop leaders. 


\section{American Journal of Pharmaceutical Education 2017; 81 (6) Article 114.}

\section{CONCLUSION}

Developing student pharmacists as leaders is instrumental in their professional development. Knowing what motivates these students to serve as leaders will better inform both college administration and organization leadership to allocate their funds so their leadership recruitment and development efforts are efficient and effective. In this study, the four most frequently mentioned motivating factors were networking, belief in the organization's mission, ability to affect change, and legacy. Based on these results, we recommend focusing recruitment efforts on these motivating factors for student leadership. Furthermore, we found that communication skills, time management, delegation, and passion/enthusiasm were the most frequently mentioned characteristics regarded as essential for student leadership. Implementing the results of this study and furthering this research will only improve the work done to create student leaders with the goal of becoming effective leaders in the field of pharmacy.

\section{REFERENCES}

1. Medina MS, Plaza CM, Stowe CD, et al. Center for the Advancement of Pharmacy Education 2013 Educational Outcomes. Am J Pharm Educ. 2013;77(8):Article 162.

2. Student Professional Organizations. http://www.utexas.edu/ pharmacy/students/organizations/index.html.

3. Kiersma ME, Plake KS, Mason HL. Relationship between admission data and pharmacy student involvement in extracurricular activities. Am J Pharm Educ. 2011;75(8):Article 155.

4. Phillips JA, McLaughlin MM, Gettig JP, Fajiculay JR, Advincula MR. An analysis of motivation factors for students' pursuit of leadership positions. Am J Pharm Educ. 2015;79(1):Article 8. 5. Seidman I. Interviewing as Qualitative Research: A Guide for Researchers in Education and the Social Sciences.4th ed. New York, NY: Teachers College Press; 2012.

6. Creswell JW. Qualitative Inquiry and Research Design: Choosing Among Five Approaches. 3rd ed. Thousand Oaks, CA: Sage Publications; 2012.

7. Moustakas C. Phenomenological Research Methods. Thousand Oaks, CA: Sage Publications; 1994.

8. Dedoose Version 7.0.23, web application for managing, analyzing, and presenting qualitative and mixed method research data (2016) [computer program]. Los Angeles, CA: SocioCultural Research Consultants, LLC. http://www.dedoose.com/. 